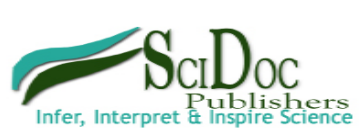

International Journal of Dairy Processing \& Research (IJDPR)

\title{
Which Milk is Fresh?
}

Research Article

Virginia L. Barraquio

${ }^{1}$ Dairy Training and Research Institute, Animal and Dairy Sciences Cluster, College of Agriculture, University of the Philippines Los Baños, College, Laguna 4031, Philippines

Abstract
The different heat treatments to which milk is subjected and their effects on milk were reviewed.Pasteurized and UHT milk which is
mislabelled as 'fresh milk' in the Philippines were compared. The commercial heat treatment processes applied to milk are: pasteuri-
zation, ultra high temperature (UHT), ultra pasteurization or super pasteurization, sterilization, and innovative steam injection (ISI).
It was shown that commercial heat treatment processes alter the heat sensitive nutrients, physico-chemical and functional properties
of milk. Higher amounts of lysinoalanine were found in UHT milk than in pasteurized milk. Further reduction in nutritional value
of UHT milk occurs in supermarket shelves where it is kept until sold and consumed. While UHT treatment is suitable for tropical
countries with high ambient temperatures and are unable to afford refrigeration during marketing and distribution, the nutritional
quality of protein is very important because in these countries, protein intake is generally low due to poverty. The Philippine food
regulatory agency allows the 'fresh milk' label on UHT milks marketed in the country. This practice does not properly inform the
consumers about the product because such milks may have been in the supermarket shelves for 6 months or more and is therefore,
no longer fresh. It also puts the locally produced fresh, pasteurized milk at a disadvantage. Although liquid milk for direct consump-
tion is not covered by Codex commodity standards, use of terms like 'natural', 'pure', 'fresh', 'home made', and 'artisan' needs to be
regulated in order to protect the consumers.
Key Words: pasteurization, super pasteurization, ultra pasteurization, ESL, UHT, ISI, sterilization, lysinoalanine, fresh,
mislabeling

\author{
*Corresponding Author: \\ Virginia L. Barraquio, \\ Dairy Training and Research Institute, \\ Animal and Dairy Sciences Cluster, College of Agriculture, \\ University of the Philippines Los Baños College, \\ Laguna 4031, Philippines \\ E-mail: vlbarraquio@gmail.com
}

Received: August 07, 2014

Accepted: August 25, 2014

Published: August 26, 2014

Citation: Virginia L. Barraquio(2014) Which Milk is Fresh?, Int J Dairy Process Res. 1:201, 1-6.

doi: http:/ / dx.doi.org/10.19070/2379-1578-140002

Copyright: Virginia L. Barraquio ${ }^{\circ} 2014$. This is an open-access article distributed under the terms of the Creative Commons Attribution License, which permits unrestricted use, distribution and reproduction in any medium, provided the original author and source are credited.

\section{Introduction}

Milk being nature's nearly perfect food is intended as the first food of all new born mammalian species. Because of milk's nutritional importance and dairy development's contribution to a country's economic growth, developing country governments like the Philippines support local dairy industry development. Despite all claims however, about milk's nutritional benefits, annual per capita consumption in the Philippines was only $22 \mathrm{~kg}$ [1]. One factor for the unpopularity of milk among consumers is the lack of 'milkculture' or milk drinking habit among the people. Another factor, a major one which principally determines milk and milk products consumption is the import dependence of the local dairy industry making dairy products unaffordable. Dairy products are the Philippines' 3rd largest agricultural import. The country's total milk supply in 2013 was 1.82 million metric tons and less than $1 \%$ of these is locally produced [1]. A significant amount of the Philippine fluid milk supply is UHT milk which is reconstituted/recombined from imported milk powder and milk fat. Thus the locally produced milk which finds good market in the specialty coffee shops still has to face competition with imported UHT milk mislabelled as 'fresh'.Local milk producers may be encouraged and locally produced liquid milk will have a competitive advantage if consumers are educated as to the real 'fresh' milk.

Fresh milk products, liquid milk for direct consumption, milk based drinks and milk based desserts are not covered by Codex commodity standards. The use of such terms like 'natural', 'pure', 'fresh', 'home made', 'artisan' may be regulated [2]. The term 'fresh' is allowed if it is in accordance with the national practices in the country where the food is sold [3].

This paper aims to explain the different heat treatments applied to milk as well as their effects on milk and to compare pasteurized versus UHT milk which is mislabelled as 'fresh milk' in the Philippines.

\section{Heat Treatment Processes Applied to Milk and their Effects}

Ages ago, it was believed that milk was created forman's use as his natural and best food and that any alteration done to it, for example, by pasteurization was unwarranted and altogether sinful [4]. This belief however, did not hold for long as heat treatment 
of milk was later realized to be essential to render milk safe for human consumption.

To date, the commercial heat treatment processes applied to milk are: pasteurization, ultra high temperature (UHT), ultra pasteurization or super pasteurization, sterilization [5,6], and innovative steam injection (ISI) [7], Table 1. All these heat treatment processes to which milk is subjected in order to render it safe and prolong its shelf-life, alter its physicochemical, nutritional and functional properties.

\section{Pasteurization}

Pasteurization is a heat treatment process applied to a product with the aim of minimizing public health hazards arising from pathogenic micro organisms associated with milk consistent with minimal chemical, physical and organoleptic changes in the product [8]. There are two methods of pasteurization: LTLT (Low Temperature, Long Time) and HTST (High Temperature Short Time). The LTLT or holder method of pasteurization involves heating milk to $63^{\circ} \mathrm{C}$ and holding at such temperature for $30 \mathrm{~min}$ utes. The HTST method of pasteurization involves heating milk at $72-75^{\circ} \mathrm{C}$ for $15-20$ seconds before it is cooled. Pasteurization kills most of the microorganisms in milk but does not render the milk sterile. Hence, pasteurized milk must be kept refrigerated, $\leq$ $4^{\circ} \mathrm{C}$ throughout distribution and storage. In the European Union, $30,000 \mathrm{cfu} \mathrm{ml}^{-1}$ is the upper limit for standard plate count of pasteurized milk and 20,000 $\mathrm{cfu} \mathrm{ml}^{-1}$ in the United States. Pasteurization is are latively mild form of heat treatment, and most consumers would probably find difficulty distinguishing between raw and pasteurized milks. Pasteurized milk has no readily apparent cooked flavour; no active sulphydryl groups are found. Whey protein denaturation is low (between 5 and 15 percent), and there is relatively little loss of the heat sensitive nutrients. The rennet coagulation properties are not affected. Enzymes are not normally a problem with pasteurized milk, mainly because the milk is used soon after processing [9]. The US FDA defines pasteurization as: heating every particle of milk or milk product, in a properly designed and operated equipment to one of the temperatures in Table 2 and held continuously at or above that temperature for at least the corresponding specified time [10].

\section{Ultrapasteurization or superpasteurization}

Ultrapasteurization or superpasteurization involves heating at temperatures above those used for pasteurization yet below those used for UHT processing. Such treatment prevent thermal alteration of the sensory properties and extend the shelf life be-

Table1. The time-temperature involved in the commercial heat treatment processes [6,7]

\begin{tabular}{|l|l|l|}
\hline Process & Temperature & Time \\
\hline $\begin{array}{l}\text { LTLT (low temperature long time) } \\
\text { Pasteurization }\end{array}$ & $63^{\circ} \mathrm{C}$ & 30 minutes \\
\hline $\begin{array}{l}\text { HTST (high temperature short time) } \\
\text { Pasteurization of milk }\end{array}$ & $72-75^{\circ} \mathrm{C}$ & $15-20$ seconds \\
\hline HTST Pasteurization of cream, etc. & $80^{\circ} \mathrm{C}$ & $1-5$ seconds \\
\hline Ultra pasteurization & $125-128^{\circ} \mathrm{C}$ & $2-4$ seconds \\
\hline UHT (ultra high temperature) & $135-140^{\circ} \mathrm{C}$ & A few seconds \\
\hline Sterilization (in container) & $115-120^{\circ} \mathrm{C}$ & $20-30$ minutes \\
\hline ISI (innovative steam injection) & $150-200^{\circ} \mathrm{C}$ & $\begin{array}{l}\text { Less than } 0.1 \\
\text { second }\end{array}$ \\
\hline
\end{tabular}

Table2. Time-temperature relationship for pasteurization as specified by US FDA's Grade A Pasteurized Milk Ordinance [11]

\begin{tabular}{|l|l|}
\hline Temperature, ${ }^{\circ} \mathbf{C}$ & Time \\
\hline $63^{\text {a }}$ & 30 minutes \\
\hline $77^{\text {a }}$ & 15 seconds \\
\hline 89 & 1 second \\
\hline 90 & 0.5 second \\
\hline 94 & 0.1 second \\
\hline 96 & 0.05 second \\
\hline 100 & 0.01 second \\
\hline
\end{tabular}

${ }^{a}$ If the fat content of the milk product is $10 \%$ or more, or if it contains added sweeteners, the specified temperature shall be increased by $3^{\circ} \mathrm{C}$.

ment is called ultra pasteurized, super pasteurized, extended shelf life (ESL) or extended long life milk. Super pasteurized milk is designed to have a shelf life of up to 90 days at refrigerated temperatures and have sensory properties superior to those of UHT milk [5]. Super pasteurized milk is processed at $125-138^{\circ} \mathrm{C}$ for $2-4$ seconds [12].

\section{Innovative Steam Injection (ISI)}

ISI is based on existing UHT equipment, but very short heating is combined with very high temperatures: less than $0.1 \mathrm{sec}$ at 150 to $200^{\circ} \mathrm{C}$ [7]. The heating is directly followed by flash cooling in a vacuum vessel. With ISI, a significant inactivation of heat resistant spores can be achieved while preserving the functionality of important ingredients. ISI results in less than 25\% denaturation of whey proteins, greater than $6 \log$ reduction in Bacillus stearothermophilus spores and 3 to $4 \log$ reduction in B. thermodurans spores. For sustained stability at room temperature, the enzymes that cause spoilage must also be inactivated. The extremely heat resistant enzyme plasmin, the instigator of bitter taste, plays the leading role here in milk products. Plasmin is not inactivated by pasteurization, but this is unimportant in pasteurized milk because the ac- 
yond that of HTST pasteurized milk. Milk subjected to this treativity of plasmin is minimal under refrigerated conditions under which pasteurized milk is stored. Besides, the germination of B. cereus spores will limit the shelf life long before the plasmin activity takes effect. To obtain an ISI milk that is stable for months at room temperature, an additional preheating step is necessary for the inactivation of plasmin. If preheating is performed, the ISI milk has under chilled condition, a substantially longer shelf life of 60 days.

Pasteurization causes only minor nutritional losses. The typical percent loss of some vitamins following pasteurization of milk are presented in Table3.

\section{UHT Treatment}

UHT treatment which renders the milk commercially sterile and shelf stable is the most common commercial heat process employed. UHT treatment made possible milk's availability worldwide especially in countries where milk is not produced. Because of the severity of heat treatment, the nutritional value of UHT processed milk is considerably reduced and further reduction in nutritive value occurs in supermarket shelves where it is kept until consumed.

The legal designation of UHT milk varies from country to country. In the United Kingdom, it is defined as the milk heated to no less than $135^{\circ} \mathrm{C}$ for at least 1 second and elsewhere processes vary from 130 to $150^{\circ} \mathrm{C}$ for 1 to 4 seconds. A more practical definition was given by Dr. Harold Burton, a pioneer of UHT milk processing- "a treatment in which product is heated to a temperature of 135 to $150^{\circ} \mathrm{C}$ in continuous flow in a heat exchanger for a sufficient length of time to achieve commercial sterility with an acceptable amount of change in the product [13].

Filipino (people of the Philippines) consumers are misled into buying UHT- processed milk because they are mislabelled 'fresh'. Such milk may have been in the supermarket shelves for 6 months or more and is therefore, no longer fresh. Moreover, the nutritional content of UHT-processed milk is considerably reduced from the heat treatment it undergoes and during the long storage life, Tables 4 and 5 .

As can be noted, there were greater losses in Vitamin C, folacin, $\mathrm{B}_{12}$, riboflavin, and thiamine in UHT than in pasteurized milk. The total loss of Vitamin $\mathrm{C}$ can be attributed to the heat instability of the oxidized form, dehydroascorbic acid and can be minimized by limiting the dissolved oxygen content of milk during handling [13].

UHT processing results in moderate denaturation of whey proteins, denaturation levels ranged from 25 to $80 \%$, depending on the process employed [16]. Heat treatment of milk above $75^{\circ} \mathrm{C}$, affects sulphur containing amino acids resulting to volatile compounds such as hydrogen sulphide and mercaptans that gives the typical cooked flavour to sterilized milk. The compounds formed

Table3. Typical percent (\%) loss of some vitamins following pasteurization of milk [12]

\begin{tabular}{|l|l|}
\hline Vitamins & \%Loss \\
\hline$A$ & Not significant \\
\hline$B_{1}$ & 10 \\
\hline$B_{6}$ & $1-5$ \\
\hline$B_{9}$ & $3-5$ \\
\hline$B_{12}$ & $1-10$ \\
\hline$C$ & $5-20$ \\
\hline$D$ & Not significant \\
\hline
\end{tabular}

Table4. Percent (\%) nutrient losses during the processingof pasteurized and UHT milk $[14 ; 13 ; 15 ; 16 ; 17 ; 18]$

\begin{tabular}{|l|l|l|}
\hline Nutrients & Pasteurized Milk & UHT Milk \\
\hline Water Soluble Vitamins & $10-25 \%$ & $\begin{array}{l}15-25 \% \text { (Direct),31.6\% (indi- } \\
\text { rect) }\end{array}$ \\
\hline Ascorbic Acid & $0-12 \%$ & $10-20 \%$ \\
\hline Folacin & $0-<10 \%$ & $0-30 \%$ \\
\hline Vitamin $B_{12}$ & $0-<10 \%$ & $0-10 \%$ \\
\hline Vitamin $B_{6}$ & $0-<1 \%$ & $0-10 \%$ \\
\hline Riboflavin & $0-10 \%$ & $<10-18 \%$ \\
\hline Thiamine & & \\
\hline Other Water Soluble Vitamins & No loss & $<10 \%$ \\
\hline Niacin & & \\
\hline Panthothenic Acid & No significant loss & No significant loss \\
\hline $\begin{array}{l}\text { Fat Soluble Vitamins } \\
\text { Vitamin A }\end{array}$ & No significant loss & No significant loss \\
\hline Protein and Amino Acids & $\begin{array}{l}\text { No considerable varia- } \\
\text { tion in calcium }\end{array}$ & $\begin{array}{l}\text { With considerable variation in } \\
\text { calcium }\end{array}$ \\
\hline Minerals and Trace Elements & \\
\hline
\end{tabular}


Table5. Effects of heat treatment on lysine and Maillard reaction products formed from lysine [19]

\begin{tabular}{|l|l|l|l|l|l|}
\hline Product & $\begin{array}{l}\text { Heat Treat- } \\
\text { ment }\end{array}$ & Lysine mg kg-1 CP & Lysinoalanine mg kg-1 CP & $\begin{array}{l}\text { Furosine mg } \\
\text { kg-1 CP }\end{array}$ & $\begin{array}{l}\text { Blocked Lysine, } \\
\%\end{array}$ \\
\hline Milk & Pasteurization & $90 \pm 5.3$ & $48 \pm 26$ & & \\
\hline \multirow{2}{*}{} & UHT & $88 \pm 6.1$ & $90 \pm 40$ & $1431 \pm 494$ & $2.7 \pm 0.9$ \\
\cline { 5 - 7 } & & $88 \pm 4.0$ & $1050 \pm 1000$ & $2 \pm 2$ \\
\hline
\end{tabular}

during the later stages of Maillard reaction are resistant to enzymic attack during digestion and thus lysine availability is reduced (Table 5). Lysine losses in UHT processed milk is about $4 \%$ as compared to losses during milk pasteurization of 1 to $2 \%$ [16].

Maillard reactions continue during storage. While UHT treatment is suitable for tropical countries with high ambient temperatures and are unable to afford refrigeration during marketing and distribution, the nutritional quality of protein is very important because in these countries, protein intake is generally low due to poverty.

Ascorbic acid loss was high during storage, for both pasteurized and UHT milk (Table 6). Most of the Vitamin C loss during storage seemed to occur in milk packaged in materials other than paper (in polyethylene or glass) $[15 ; 20 ; 21]$ when these packages are exposed to light. For UHT milk, the content and availability of oxygen were the factors most detrimental to the stability of vitamin C. In general, milk with high oxygen content were processed in UHT plants without vacuum flash down system (most indirect processes) or packed into containers with head spaces of air. If the milk is saturated with oxygen, virtually all of the ascorbic and folic acid will be lost within a few minutes of storage[16]. Exposure to light was cited as the main factor for riboflavin loss for both pasteurized and UHT milk [15] and so with vitamin A [28].
Maillard reactions continue during storage of UHT milk with their rate being dependent on storage conditions. The nutritional quality of proteins is slowly degraded as a result of these reactions with, for example, caseins being resistant to enzymic digestion. After extended storage at high temperatures (6 months at 30 to $37^{\circ} \mathrm{C}$ ) up to $30 \%$ of the lysine may become unavailable. This storage temperature approximates ambient temperature in the tropics and thus lysine losses in unrefrigerated UHT milks could reach significant levels [16].

\section{Sterilization}

Sterilization involves heat treatment in excess of $100^{\circ} \mathrm{C}$ and packaging in air tight containers either before or after heat treatment. If packaging done after heat treatment, aseptic packaging is very important. Such milks are called sterilized milk. Sterilized milk is not necessarily free of microorganisms and is said to be commercially sterile. However, those micro organisms which survive the heat treatment are unlikely to proliferate during storage and cause spoilage of the milk [9].

Continuous sterilization, in-container sterilization in autoclaves at 105 to $120^{\circ} \mathrm{C}$ for 10 to 40 minutes, and ultra high temperature treatment (UHT) are used to sterilize milk and milk prod-

Table6. Percent(\%) nutrient losses during the storage of pasteurized and UHT milk $[20 ; 21 ; 15 ; 22 ; 23 ; 24 ; 25 ; 26 ; 27 ; 17]$

\begin{tabular}{|c|c|c|}
\hline Nutrients & Pasteurized Milk & UHT Milk \\
\hline \multicolumn{3}{|l|}{ Water Soluble Vitamins } \\
\hline Ascorbic Acid & $\begin{array}{l}15-95 \% \text { plastic package, } 54-84 \\
\% \text { paper package }\end{array}$ & $0-80 \%$ \\
\hline Folacin & No significant loss & No significant loss \\
\hline Vitamin $\mathrm{B}_{12}$ & No significant loss & $0-100 \%$ \\
\hline Vitamin $\mathrm{B}_{6}$ & No significant loss & $14-50 \%$ \\
\hline Riboflavin & $4.5-15 \%$ & $0-<10 \%$ \\
\hline Thiamine & $<10 \%$ & $10-18 \%$ \\
\hline $\begin{array}{l}\text { Other Water Soluble Vitamins } \\
\text { (Niacin, Panthothenic Acid, } \\
\text { Biotin) }\end{array}$ & Niacin- no significant loss & $\begin{array}{l}\text { Niacin- } 10 \%, \quad \text { Panthothenic } \\
\text { Acid-0-30\%, Biotin-no significant } \\
\text { loss }\end{array}$ \\
\hline $\begin{array}{l}\text { Fat Soluble Vitamins } \\
\text { Vitamin A }\end{array}$ & $\begin{array}{l}0-<10 \% \text { - not fortified } \\
20-95 \% \text { - fortified }\end{array}$ & $\begin{array}{l}0-62 \% \text { - not fortified } \\
11-90 \% \text { - fortified }\end{array}$ \\
\hline Protein \& Amino Acids & $\begin{array}{l}\text { No significant loss (lysine, methio- } \\
\text { nine, cysteine) }\end{array}$ & $0-<5 \%$ \\
\hline
\end{tabular}

ucts. Shorter holding periods are used with higher temperatures. The objective of sterilization is to produce a long life product by destruction of microorganisms of public health significance and microorganisms capable of spoilage. The US Food and Drug Administration requires temperature-time combinations that will ensure a reduction of Clostridium botulinum spores by $12 \mathrm{log}$. However,in order to obtain commercial long-life stable milk and milk products, the thermal treatment conditions required to deliver a $12 \log$ reduction of Clostridium botulinum have to be extended depending on the product, for example, for sterile milk, the conditions are based on the reduction of thermophilic spores by $9 \log [29]$. The high temperature used induce a number of physical and chemical changes in the milk (Table 7).

Sterilized milks prepared by direct UHT method are shelf stable for up to 12 to 6 months at a storage temperature of 4 and $20^{\circ} \mathrm{C}$, respectively, while that produced by the indirect process is shelf stable for more than 12 months at $4^{\circ} \mathrm{C}$ and up to one year at $20^{\circ} \mathrm{C}$. Sporicidal effect of UHT and retort sterilization are equal. Adverse effects on color, flavour and nutritional value are 
Table7. Some chemical, enzymatic and physical phenomena that occur during manufacturing and storage of sterilized milk products [30].

\begin{tabular}{|l|l|}
\hline Component or Property & Phenomena \\
\hline Proteins & $\begin{array}{l}\text { Unfolding, denaturation }(50-85 \%) \text {, formation of complexes with } x \text {-casein, } \\
\text { increase in proportion of non- sedimentable casein, proteolysis during stor- } \\
\text { age, increase in proportion of NPN and noncasein N, polymerization during } \\
\text { storage, formation of lactulosyl lysine and fructosyl lysine during storage }\end{array}$ \\
\hline Minerals & $\begin{array}{l}\text { Decrease in proportion of ionic Caand Mg due to precipitation as } \text { PO }_{4} \text { during } \\
\text { processing, partial reversal of the latter during storage }\end{array}$ \\
\hline Lactose & Maillard reaction, isomerization to lactulose \\
\hline Rennet coagulation time & Increases with both UHT and retort sterilization \\
\hline Sensitivity to alcohol & $\begin{array}{l}\text { UHT milk: increases during storageRetort sterilized milk: unchanged during } \\
\text { storage }\end{array}$ \\
\hline Sensitivity to Ca & UHT: significant increase during storage Retort: some increase during storage \\
\hline Lipids & Lipolysis by heat resistant or reactivated lipases during storage \\
\hline
\end{tabular}

significantly lower in the UHT process.

Age gelation is an irreversible phenomena that occurs during storage of sterilized milk andthis is affected by the combined influence of a multitude of variables related to milk composition and quality as well as to process and storage conditions. Seasonality, breed and stage in the lactation cycle and health of the animal affect gelation properties of sterilized milk products, through their influence on milk composition and physicochemical properties. The gelation-free storage time of sterilized milk is inversely related to the microbiological load in the milk especially the presence of microorganisms that produce stable proteases, such as those originating from psychrotrophs.

Temperatures used for milk sterilization introduce a whitening effect which has been attributed to the time and temperature dependent effect on mineral distribution and especially on denaturation of whey proteins, especially $\beta$-lactoglobulin and the formation of complexes between the latter and K-casein at the surface of the casein micelles. Such interactions modify the light reflectance properties of milk, hence make sterilized milk whiter.

Intensity of flavour notes typical to UHT and in-container sterilized milk has been shown to correlate well with the accumulation of lactulose. Flavour acceptability of sterilized milk is critically dependent on the level of free-SH groups, originating from the effect of heat treatment on whey protein, and are responsible for the strong hydrogen sulphide odour of fresh sterilized milk. The level of these compounds declines rapidly, due to oxidation, with storage time, at a rate that is proportionately related to the level of oxygen in the product. The rate and extent of Maillard reaction that occurs during storage contributes to the decline of flavour quality of UHT milk[30].

Oil soluble vitamins (A, D, E) as well as some water soluble vitamins (riboflavin, nicotinic acid, biotin) are heat stable and are not adversely affected by either in-container or UHT process. Folic acid, vitamin $\mathrm{B}_{12}$ and ascorbic acid are lost to different extents. Vitamin C loss is due not only to heat treatment but also oxidation prior to heat treatment. The oxidized form is heat labile and is likely to be completely destroyed during UHT process while loss of only $10-20 \%$ of the reduced form can be expected. Loss of vitamin $\mathrm{B}_{12}$ is linked tooxidative destruction of vitamin $\mathrm{C}$. The loss of folic acid is limited by the protection provided by the reduced form of vitamin $\mathrm{C}$, and thus, destruction of the latter will affect the loss of the former [31,32].
Lipolysis was cited as one of the factors to consider in certain milk applications such as foaming, along with fats and proteins, as well as their interaction with other components and environmental factors such as temperature (microwave heating), levels of free fatty acids/titratable acidity and $\mathrm{pH}[33,34]$

\section{Conclusions}

Loss of ascorbicacid, folacin, vitamin $\mathrm{B}_{12}$, riboflavin, thiamine, niacin and panthothenic acid and effect on calcium was greater in UHT than in pasteurized milk. More losses of ascorbic acid, vitamins $B_{12}, B_{6}$, thiamine, niacin, panthothenic acid, and vitamin A were reported during storage of UHT milk. Higher amounts of bound lysine (lysinoalanine) was found in UHT than in pasteurized milk. Moreover, properties such as rennet coagulation time, flavour and foam ability were adversely affected during manufacturing and storage of sterilized milk products. Thus, it was shown that commercial heat treatment processes alter the heat sensitive nutrients, physico-chemical and functional properties of milk.

The Philippine food regulatory agency allows the 'fresh milk' label on UHT milks marketed in the country. This practice does not properly inform the consumers about the product because such milks may have been in the supermarket shelves for 6 months or more and is therefore, no longer fresh, besides putting the locally produced fresh milk at a disadvantage. The food regulatory agency and a multinational company that supplies alarge volume of UHT milk contends that 'fresh'may be used provided the said product still conform with the definition of milk which comes from the cow and has not less than the required fat and MSNF. The decision however, was silent about recombined and reconstituted UHT milks which are also mislabelled as 'fresh'. While liquid milk for direct consumption is not covered by Codex commodity standards, use of terms like 'natural', 'pure', 'fresh', 'home made', and 'artisan' must be regulated to protect consumers.

\section{References}

[1]. gain.fas.usda.gov/Recent $\%$ GAIN $\%$ Publications/Dairy $\% 20$ Products $\% 20$ Annual_Manila_Philippines-10-10.Retrieved June 21, 2014

[2]. Heggum C (2003) "Labelling of dairy products". In: Encyclopedia of Dairy Sciences. Vol. 3. H.Roginski, J.W. Fuquay and P.F. Fox (Eds). Academic Press, New York pp 1429-1435

[3]. CAC/GL 1-1979 (1991) Section 5.1 (iii) of Codex General Guidelines on 
Claims, Revised 1991. FAO/WHO, Rome,Italy

[4]. Kon SK (1976) Milk in nutrition: Technological and changingviews. Neth. Milk Dairy J. 30:149-156

[5]. Rankin SA (2003) “Superpasteurized milk". In: Encyclopedia of Dairy Sciences. Vol. 3. H. Roginski, J.W. Fuquay and P.F. Fox (Eds). Academic Press, New York pp 1633-1637

[6]. De Jong P (2008) “Thermal Processing of Milk". Advanced Dairy Science and Technology. T.J. Britz and R.K. Robinson (Eds). Blackwell Publishing, Ltd, Oxford, UK pp1-34

[7]. Huijs G, van Asselt AJ, Verdurmen REM and de Jong P (2004) High speed milk, a new way of treating milk. Dairy Industries International pp 30-32. In: De Jong P (2008) “Thermal Processing of Milk”. In: Advanced Dairy Science and Technology. T.J. Britz and R.K. Robinson (Eds). Blackwell Publishing, Ltd, Oxford, UK pp1-34

[8]. IDF (International Dairy Federation) (1994) Pasteurization and other heat treatment processes. Document 292: 13-16, International Dairy Federation, Brussels, Belgium

[9]. Lewis MJ (1986) "Advances in the Heat Treatment of Milk". Modern Dairy Technology Vol 1. R.K. Robinson (Ed). Elsevier Applied Science Publishers, London pp 1-50

[10]. US FDA (Food and Drug Administration) (1999) Grade A Pasteurized Milk Ordinance. US FDA, Washinton,DC

[11]. Meunier-Goddik L and Sandra S (2003) "Liquid milk products". In: Encyclopedia of Dairy Sciences. Vol. 3. H. Roginski, J.W. Fuquay and P.F. Fox (Eds). Academic Press, New York pp 1627-1632

[12]. Busse M (1981) IDF Document No. 130. In: Lewis MJ (1986) "Advances in the Heat Treatment of Milk". Modern Dairy Technology Vol 1. R.K. Robinson (Ed). Elsevier Applied Science Publishers, London pp 1-50

[13]. Varnam AH and Sutherland JP (1994) "Liquid milk and liquid milk products". Milk and Milk Products. Technology, Chemistry and Microbiology. Chapman and Hall, London pp 42-102

[14]. Amantea GF (1983) Aseptic packaging of dairy products. Food Technol 37: 138-142

[15]. Andersson I and Oste R (1995) Nutritional quality of heat processed milk. International Dairy Federation, Brussels

[16]. Zadow JG (1984) The effect of new technology on the nutritional value of dairy products. Austr. J. Dairy Technol. 39:104-108

[17]. Blanc B (1980) Einfuss der termischen Behandlung auf die wichtigsten Milchinhaltsstofe aund auf den Ernahrungsphysiologischen vert der Milch. Aalimenta 5-25

[18]. Farrell HM Jr and Douglas FW (1983) Effects of ultra high temperature pasteurization on the functional and nutritional properties of milk proteins. Milchwirtsch. Forchungsber. 35: 345-356
[19]. Erbersdobler HF, Drusch S and Faist V (2003) "Effects of processing on protein quality of milk and milk products". In: Encyclopedia of Dairy Sciences. Vol. 4. H. Roginski, J.W. Fuquay and P.F. Fox (Eds). Academic Press, New York pp 2137-2143

[20]. Dimick PS (1973) Effect of fluorescent light on the flavour and selected nutrients of homogenized milk held in conventional containers. J. Milk Fd. Technol. 36: 383-387

[21]. Allen JC and Joseph B (1985) Deterioration of pasteurized milk on storage. J. Dairy Res. 52: 469-487

[22]. Kneifel W and Sommer R (1986) Zum lagerungsbedingten Abbau einiger waserloslicher vitaminein Haltbarmilch. Osterreichische Milchwirtchaft 41: $79-87$

[23]. Oamen EE, Hansen AP and Swartzel KR (1989) Effect of ultra high temperature steam injection processing and aseptic storage on labile water soluble vitamins in milk. J. Dairy Sci. 72: 614-619

[24]. Glass L and Hedric TI (1974) Changes in milk packaged in paper board or plastic containers.Proc. XIX Int. Dairy Congr. (New Delhi) IE 582-58

[25]. Scott KJ and Bishop DR (1986) Nutrient content of milk and milk products: vitamins of the $\mathrm{B}$ complex and vitamin $\mathrm{C}$ in the retail milk and milk products. J. Soc. Dairy Technol.39: 32-35

[26]. Gorner Fand Uroheva R (1980) Vitaminveranderungen der H-Milchwahrend der Lagerung. Nahrung24: 373-379

[27]. Ford JE, Porter JWG, Thompson SY, Toothill J and Edward-Webbs J (1969) Effects of ultra high temperature (UHT) processing and of subsequent storage on the vitamin content of milk. J. Dairy Res.36: 447-454

[28]. Anonymous (1990) UHT milk in returnable bottles. Molkerei-ZeitungWelt-der-Milch 44: 1348-1350

[29]. Hinrichs J and Rademacher B (2003) "Sterilization of milk and other products”. ”. In: Encyclopedia of Dairy Sciences. Vol. 4. H. Roginski, J.W. Fuquay and P.F. Fox (Eds). Academic Press, New York pp 2569-2576

[30]. RosenbergM (2003) "Sterilized milk". In: Encyclopedia of Dairy Sciences. Vol. 3. H. Roginski, J.W. Fuquay and P.F. Fox (Eds). Academic Press, New York pp 1637-1646

[31]. Ford JE and Thompson SY (1981) The nutritive value of UHT milk. International Dairy Federation, Brussels, IDF Bulletin 133: 65-70

[32]. Burton H (1988) Ultra High Temperature Processing of Milk and Milk Products. Elsevier Applied Science Publishers, London

[33]. Gamboa GV and Barraquio VL (2012) Foaming properties at different fat levels and age of milk. Phil. Agric. Scientist 95: 391-396

[34]. Kammath S, Wulandewi A and Deeth HC (2008) Relationship between surface tension, free fatty acid concentration and foaming properties of milk. Food Res. Intl. 4: 623-629 